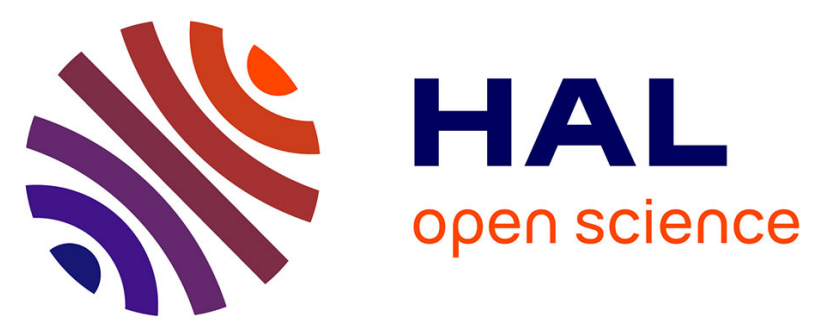

\title{
Assessment of Open Government Data Initiative - A Perception Driven Approach
}

\author{
Alka Mishra, D. P. Misra, Arpan Kumar Kar, Sunil Babbar, Shubhadip \\ Biswas
}

\section{To cite this version:}

Alka Mishra, D. P. Misra, Arpan Kumar Kar, Sunil Babbar, Shubhadip Biswas. Assessment of Open Government Data Initiative - A Perception Driven Approach. 16th Conference on e-Business, eServices and e-Society (I3E), Nov 2017, Delhi, India. pp.159-171, 10.1007/978-3-319-68557-1_15 . hal-01768497

\section{HAL Id: hal-01768497 \\ https://hal.inria.fr/hal-01768497}

Submitted on 17 Apr 2018

HAL is a multi-disciplinary open access archive for the deposit and dissemination of scientific research documents, whether they are published or not. The documents may come from teaching and research institutions in France or abroad, or from public or private research centers.
L'archive ouverte pluridisciplinaire HAL, est destinée au dépôt et à la diffusion de documents scientifiques de niveau recherche, publiés ou non, émanant des établissements d'enseignement et de recherche français ou étrangers, des laboratoires publics ou privés. 


\title{
Assessment of Open Government Data Initiative - A Perception Driven Approach
}

\author{
Alka Mishra ${ }^{1}$, D. P. Misra ${ }^{1}$, Arpan Kumar $\mathrm{Kar}^{2}$, Sunil Babbar ${ }^{1}$ and Shubhadip \\ Biswas*3 $^{* 3}$ \\ ${ }^{1}$ National Informatics Centre, Delhi \\ 2 DMS, Indian Institute of Technology, Delhi \\ ${ }^{3}$ Open Government Data Project, Delhi \\ *shubhadip.biswas@live.com
}

\begin{abstract}
Evolution of Information and Communications Technologies (ICT) and digital governance became the key enablers for open data initiative of the government to become more open, responsive, inclusive, transparent, accountable and efficient. Through the e-governance initiatives governments worldwide are focusing on the concept of open data and its huge potential to bring positive changes to the socio-economic value by developing and disseminating information within a vibrant mixed economy comprising of open source, government bodies, business houses, and hybrid solutions of various forms fueled with the sharp elevation of digitization. This study demonstrates assessment of open government data initiatives by the geometric mean method (GMM) of analytical hierarchy process (AHP). Few key factors i.e. people, technology scope, policy, economic and institution were identified which have a very strong impact for any e-governance initiative.
\end{abstract}

Keywords: E-Governance, Open Data, Analytic Hierarchy Process, Impact Assessment, Feature Prioritization.

\section{Introduction}

The digital space is increasing rapidly throughout the world. Public and organizations are using more and more digital mechanism to interact with each other, and to transact day to day business. Nowadays, the focus of the governments across the world are mainly to develop competences to deliver public services using ICT to various stakeholders [19]. E-governance works as a catalyst to improve the public service quality, effectivity, and efficiency, to improve the decision-making process and to promote citizen centric governance. To promote access of publicly held information, promoting transparency and enabling wider socio-economic gain, need has been realized in India that there must be a mechanism for proactive share and free access of the data originated from public funds and which are available with various government bodies. As a result, in 2012, the open government data initiative in India moved towards a new dimension with the notification of the National Data Sharing and Accessibility Policy (NDSAP), $\&$ in pursuance of the policy, the Open Government Data (OGD) platform - India 
(https://data.gov.in) was developed and launched to facilitate share and free access of data through an efficient and dynamic process.

Many assessment frameworks have been developed, primarily with an objective to address e-governance initiatives. According to various studies, user perspectives, scope of information technology, government policies and regulations, economic benefit and government are very important parameters to understand any e-governance initiative [22]. In this study, the analytical hierarchy process (AHP) has been applied to assess open government data initiatives by group decision making approach for the prioritization among assessment factors and constructs. This study illustrates the application of the geometric mean method (GMM) and its theories to prioritize the assessment criterions of Indian open government data initiative.

\section{Review of Literature}

\subsection{E-Governance Project Assessment}

E-governance can have a major impact in socio-economic development by transforming the public administration mechanism. E-Governance is the process to enable government using ICT to make governance effective for citizens in terms of effectiveness and efficiency in public service, decision-making process, transparency, citizen centric governance, socio-economic development and cost-effectiveness [42].

According to reviews of literature on assessment of e-governance projects [22] various constructs may be clubbed in to factor groups like people, technology scope, policy, economic and institution. Within these factors, constructs were identified based on prominence and dominance in existing literature. Clubbing of these constructs were also done within these factors based on having the similar dimensions and characteristics. The Table 1 provide information of each constructs in the factor group.

Table 1. Details of construct groups for e-governance Assessment

\begin{tabular}{|l|l|l|r|}
\hline \multirow{3}{*}{$\begin{array}{c}\text { Factor } \\
\text { group }\end{array}$} & \multicolumn{1}{c|}{$\begin{array}{c}\text { Construct sub- } \\
\text { group }\end{array}$} & \multicolumn{1}{c|}{ Construct item } & $\begin{array}{c}\text { Cross-refer- } \\
\text { ence of Con- } \\
\text { struct to } \\
\text { publications }\end{array}$ \\
\hline \multirow{4}{*}{ People } & \multirow{3}{*}{$\begin{array}{l}\text { Individual percep- } \\
\text { tions }\end{array}$} & Adoption & 31 \\
\cline { 3 - 4 } & & Ease of use & 5 \\
\cline { 3 - 4 } & Social perceptions & Perceived usefulness & 31 \\
\cline { 3 - 4 } & Awareness & User satisfaction & 2 \\
\hline \multirow{4}{*}{$\begin{array}{l}\text { Technol- } \\
\text { ogy Scope }\end{array}$} & \multirow{2}{*}{ Technological } & User awareness & 43 \\
\cline { 3 - 4 } & & Accessibility & 38 \\
\cline { 3 - 4 } & & Infrastructure & 44 \\
\cline { 3 - 4 } & System maturity & Reliability & 32 \\
\cline { 3 - 4 } & & Technological risks & 12 \\
\hline Policy & & Website maturity & 34 \\
\hline
\end{tabular}




\begin{tabular}{|c|c|c|c|}
\hline & \multirow{4}{*}{$\begin{array}{l}\text { Information govern- } \\
\text { ance }\end{array}$} & Privacy & 16 \\
\hline & & Security & 43 \\
\hline & & Transparency & 5 \\
\hline & & User trust & 39 \\
\hline & \multirow{2}{*}{ Outcome based } & Effectiveness & 23 \\
\hline & & Empowerment & 4 \\
\hline \multirow{5}{*}{ Economic } & \multirow{3}{*}{ Individual } & Affordability & 32 \\
\hline & & Cost of service & 9 \\
\hline & & Cost saving & 40 \\
\hline & \multirow{2}{*}{ Government } & Cost & 46 \\
\hline & & Funding sustainability & 49 \\
\hline \multirow{6}{*}{ Institution } & Management & Management support & 44 \\
\hline & \multirow{3}{*}{ Operational } & Availability & 20 \\
\hline & & Operational efficiency & 43 \\
\hline & & Performance & 16 \\
\hline & \multirow{2}{*}{ Quality } & Information quality & 5 \\
\hline & & Service quality & 2 \\
\hline
\end{tabular}

\subsection{Open Government Data Initiative}

The concept of open government data has been popularized significantly, with the demand being placed on all kinds of government bodies to release the data for open access [47]. Open access to government data, can help government to become more open, responsive, inclusive, transparent, accountable and efficient, can provide greater returns from the public-sector investment [33], can create new economy through the downstream use of outputs, can help policy makers in data driven decision making [7], and can motivate the citizens in proactive innovation using government data [25] or participate in policy-making [8]. Participatory governance would evolve into a heightened accountability that in result curbs corruption [35]. Open government data has the potential to increase productivity, to improve products and services by value addition to the original open government data and most importantly to make way for the datadriven innovation with new age products and services [34]. Moreover, it galvanizes creation of new firms and companies. In 2012, Indian government had formulated National Data Sharing and Accessibility Policy (NDSAP) [37] and under the mandate of NDSAP, the Open Government Data (OGD) platform - India (https://data.gov.in/) was developed and launched. Though there is a drastic increase in open datasets across the world, it is still a big hurdle to reach to the full potency of this initiative and actively engage all stakeholders with the initiative [47,48]. Several factors, including stakeholder engagement, technical scope, regulations and policies, economical and institutional [13], contribute to this obstacle [51].

The factor groups i.e. people, technology scope, policy, economic and institution, which have been emerged for e-governance project assessment have been detailed below in the context of open government data initiative India. 
People. India's Open Government Data (OGD) platform has a rich framework for citizen engagement, which could help government bodies to prioritize the release of open government data. The platform also acts as a knowledge-sharing platform through online communities. Citizens with specific interests are encouraged to contribute blogs and join online sector specific forums of their domain of interest, it enables communities to express their requirement for datasets or applications, to rate the dataset quality, provide suggestions and feedbacks, and seek clarification or information. Indian open government data initiative also engaged with various stakeholders through various citizen and community collaboration initiatives by organizing various workshops, hackathons, application challenges, etc.

As per open government data initiative constructs under 'people' group are engagement and adaptation of open government data by civil society, participatory governance for social benefit through collaboration with all stakeholders i.e. government bodies, academia, private organizations and people, awareness of open government data among citizens, user friendly and ease of use of platform, perceived usefulness of open government data among users \& user satisfaction on open government data.

Technology Scope. The OGD platform was developed using open source stack, with focus on proactive dissemination of open government resources i.e. data, applications, tools, etc. in open format. The platform has a configurable multilevel workflow module to be used by government bodies to contribute, review, approve and publish open data, it has configurable and scalable modules i.e. data management, content management, visitor relationship management, community, blog, visualization, dataset conversion tool, APIs etc. [34]. The OGD platform is also offering the platform under software as a service (SaaS) model, which has helped states and urban local bodies to create their own open government data portal. As per open government data initiative constructs under 'technology scope' group are accessibility of open government data, infrastructure of Open Government Data (OGD) platform and to build new products/services based on open government data, reliability of open government data, website maturity/stability of Open Government Data (OGD) platform \& technological risk for uninterrupted access of open government data.

Policy. Under open government data initiative, the National Data Sharing and Accessibility Policy (NDSAP) was designed to apply to all sharable and non-sensitive data available and generated using public funds by government bodies. Open data \& NDSAP implementation guidelines [24] provide guidelines on data, metadata, and implementation methodologies, role of chief data officer (CDO), NDSAP cell, data contributor, publishing \& management of resources, etc. [36]. Government Open Data License - India [21] was gazette notified on $10^{\text {th }}$ February 2017 , to provide a legal framework to the data users wishing to use and build on top of public data. License also gives assurance of what they legally can and can't do with the data both commercially and non-commercially. In NDSAP and Government Open Data License, special care has been taken to protect privacy, security and sensitive information. As per open government data initiative constructs under 'policy' group are existence of open government 
data sharing policy and open government data license, policy to empower citizens to take informed and data driven decision, effectiveness of open government data, policy to make data authentic and reliable to build trust of the users, security policies for website and data, accountable and transparent governance by sharing open government data $\&$ protection of privacy and sensitive information in open government data.

Economic. Open data can be described as a data which anyone is free to use, reuse, and redistribute. So, freeness is an integral part of open data, users can easily avail free of cost open government data from OGD platform. Ready availability of open government data in a single centralized platform is not only saving the monetary cost but also the time cost. Following the mandate of the National Data Sharing and Accessibility Policy (NDSAP), in the Government Open Data License - India, all users have been provided a worldwide, royalty-free, non-exclusive license to use, adapt, publish (either in original, or in adapted and/or derivative forms), translate, display, add value, and create derivative works (including products and services), for all lawful commercial and noncommercial purposes. As per open government data initiative constructs under 'economic' group are cost of accessing open government data, affordability of using open government data services, cost saving due to open government data, cost to government for sharing open government data and sustainable funding for open government data initiative.

Institution. To implement NDSAP policy under open government data initiative rich sharing framework has been developed to manage contribution, approval and publishing process of open government data. As per the mandate of NDSAP, a senior officer is to be nominated as the nodal officer or chief data officer from the departments/organizations/states. The responsibility of chief data officer is to spearhead the initiative of the respective department/organization/state. For operation efficiency and for proactive share of the data, there is provision for chief data officer to nominate several data contributors who would contribute datasets along with the metadata on the OGD platform. Special care has been taken in NDSAP guidelines to maintain quality of data and metadata. As per open government data initiative constructs under 'institution' group are management support for open government data initiative, availability of datasets, operational efficiency to share the datasets, performance of open government data sharing mechanism, quality of services provided by Open Government Data (OGD) platform \& quality of open government data/metadata.

\section{Computational Approach using Analytic Hierarchy Process}

Analytic Hierarchy Process (AHP) is one of the robust multi criteria decision making method, in short, it is a process to derive ratio scales from paired judgments based on psychology and mathematics. The analytical hierarchy process (AHP) has been applied in this study to assess open government data initiatives by providing group decision 
support $[6,26,27,28,29,30]$. This study explores the suitability and applicability of the geometric mean method (GMM) and its theories to prioritize the assessment criterions of Indian open government data initiative.

\subsection{Measurement of individual decisions}

Let $B=\left(b_{1}, b_{2}, \ldots, b_{5}\right)$ be the consensus vector where $b_{i}$ represents the " $i_{t h}$ " criterion's priority, estimated as $\sum b_{i}=1$. Let $V=\left(v_{1}, v_{2}, \ldots, v_{n}\right)$ be the set of $n$ expert decision makers with a relative importance of $\phi_{\mathrm{i}}$ and $\phi=\left(\phi_{1}, \phi_{2}, \ldots, \phi_{\mathrm{n}}\right)$ is the weight vector of the decision makers and $\sum \phi_{\mathrm{i}}=1[26]$.

Shanon function maximization approach for the middle element can be used to optimize the unpredictability of an individual preference as $S(\mu)=\mu \ln \mu-(1-\mu) \ln (1-\mu)$ [50]. The pairwise comparison approach [10] has been used for fuzzy set operations and for the operator $\diamond$ used as an illustration, it has been shown for the fuzzy sets $\tilde{b}_{i}$ and $\tilde{b}_{j}: \tilde{b}_{i} \diamond \tilde{b}_{j}=\left(\tilde{b}_{i, 1}, \tilde{b}_{i, 2}, \tilde{b}_{i, 3}\right) \diamond\left(\tilde{b}_{j, 1}, \tilde{b}_{j, 2}, \tilde{b}_{j, 3}\right)=\left(\left(\tilde{b}_{i, 1} \diamond \tilde{b}_{j, 1}\right),\left(\tilde{b}_{i, 2} \diamond \tilde{b}_{j, 2}\right)\right.$, $\left.\left(\tilde{b}_{i, 3} \diamond \tilde{b}_{j, 3}\right)\right)$

\subsection{Measurement of individual condition of consistency}

The pair wise matrix i.e. $\mathrm{K}=\left(\tilde{k}_{\mathrm{ij}}\right)_{\mathrm{n} \times \mathrm{n}}$ is an $\mathrm{n} \times \mathrm{n}$ real matrix, for a decision maker $\mathrm{v}_{\mathrm{i}}$, where $\mathrm{n}$ is the number of evaluation criteria considered and $\tilde{k}_{\mathrm{ij}} \geq 0$. the entries $\tilde{k}_{\mathrm{ij}}$ and $\tilde{k}_{\mathrm{ji}}$ satisfy the constraint: $\tilde{k}_{\mathrm{ij}} \times \tilde{k}_{\mathrm{ji}}=1$. In the eigenvector method (EVM) it derives values (priorities) $\left(\mathrm{w}_{1}, \mathrm{w}_{2}, \ldots \mathrm{w}_{\mathrm{n}}\right)$ of comparable elements as the linear solution of the eigenvalue problem [41]:

$\sum_{i=1}^{n} \tilde{k}_{i, j} w_{i}=\lambda_{\max } w_{i}, \mathrm{e}^{\mathrm{T}} \mathrm{w}=1$ where $\mathrm{i}=1,2, \ldots, \mathrm{n}$

Equation for the individual decision vector:

$\min \sum_{i=1}^{n} \sum_{j>i}^{n}\left(\ln \tilde{k}_{i, j}-\left(\ln \widetilde{w}_{i}-\ln \widetilde{w}_{j}\right)^{2}\right)$ such that $\widetilde{w}_{\mathrm{i}} \geq 0$ and $\sum \widetilde{w}_{\mathrm{i}}=1$

The solution is obtained by $\widetilde{w}_{i}=\frac{\sqrt[1 / n]{\prod_{j=1}^{n} \tilde{k}_{i, j}}}{\sum_{i=1}^{n} \sqrt[1 / n]{\prod_{j=1}^{n} \tilde{k}_{i, j}}}$

where $\widetilde{W} \mathrm{i}$ is the judgement criteria's weight so that $\widetilde{W}_{i}=\left\{\widetilde{w}_{1}, \widetilde{w}_{2}, \ldots, \widetilde{w}_{7}\right\}$ for $\mathrm{i}_{\text {th }}$ decision maker.

$$
\operatorname{GCI}\left(K^{v_{i}}\right)[14]=\frac{2}{(n-1)(n-2)} \sum_{j>i}^{n}\left(\log \left|\tilde{k}_{i, j}\right|-\left(\log \widetilde{w}_{i}|-\log | \widetilde{w}_{j} \mid\right)^{2}\right)
$$

Aguarón and Moreno-Jiménez (2003) [1] has proposed a corresponding threshold for $\mathrm{GCI}_{\mathrm{n}}$ i.e. $\mathrm{GCI}_{3}<0.0314, \mathrm{GCI}_{4}<0.0352, \mathrm{GCI}_{\mathrm{n}}<0.037$ (for $\mathrm{n}>4$ ). The analysis of the Saaty's criterion exhibits that this criterion is not an acceptable EM error indicator [45]. The condition for consistency can be GCI $\left(K^{v_{i}}\right) \leq \overline{G C I}[11]$. 


\subsection{Aggregation of individual priorities}

Aggregation of preferences of individual: $\tilde{k}_{i j}^{(c)}=\prod_{m=1}^{t}\left(\tilde{k}_{i j}^{(m)}\right)^{\phi m}$

A vector can be formulated by GMM where $\mathrm{w}_{\mathrm{i}}{ }^{(\mathrm{c})}$ is the vector such that $\mathrm{w}_{\mathrm{i}}^{(\mathrm{c})}=\left\{\widetilde{w_{1}}{ }^{(\mathrm{c})}, \ldots .{\widetilde{w_{7}}}^{(\mathrm{c})}\right\}^{\mathrm{T}}$ and $\phi_{\mathrm{i}}$ is the importance of expert decision maker $\mathrm{v}_{\mathrm{i}}$. The equation of conversion of the fuzzy weights to crisp weights has been shown below:

$$
\left|\widetilde{w}_{i}\right|=\left[\left(w_{i, 1} \times 0.25\right)+\left(w_{i, 2} \times 0.50\right)+\left(w_{i, 3} \times 0.25\right)\right]
$$

\subsection{Achieving consensus in priorities of user groups}

$$
\operatorname{GCCI}\left(K^{v(c)}\right)=\frac{2}{(n-1)(n-2)} \sum_{j>i}^{n}\left(\log \left|\tilde{k}^{(c)}{ }_{i, j}\right|-\left(\log \left|w^{(c)}{ }_{i}\right|-\log \left|w^{(c)}{ }_{j}\right|\right)^{2}\right)
$$

Consensus is achieved if $\mathrm{GCCI}\left(K^{v}(c)\right) \leq \overline{G C C I}$ for, $\mathrm{GCCI}_{\mathrm{n}}<0.037$ (for $\mathrm{n}>4$ ) [17]. If $\operatorname{GCCI}\left(K^{v}(c)\right) \geq \overline{G C C I}$, to achieve group consensus following computations need to be completed [15]: Assume $\operatorname{GCCI}\left(K^{v(\tau)}\right)=\max _{c}\left\{\operatorname{GCCI}\left(K^{v_{(c)}}\right)\right\}$ where $\mathrm{z}=\max _{n} z+1$,

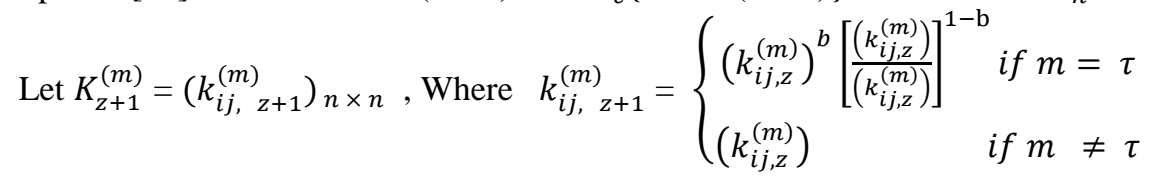

1. If $\operatorname{GCCI}\left(K_{z}{ }^{{ }(c)}\right) \leq \overline{G C C I}, \mathrm{X}=K_{z}{ }^{\mathrm{v}(c)}$ else return to $1^{\text {st }}$ process.

\section{Data Collection and Analysis}

After studying various literatures on assessment of e-governance project important constructs were identified and those have been clubbed in to factor groups like people, technology scope, policy, economic and institution.

The data for AHP for assessment of open data initiatives, were collected from fiftyeight senior government officials, and experienced open data activist, these domain experts were very actively engaged in the open data activities at least for last six years. The priorities of these fifty-eight domain experts had equal importance in decision making. These group of experts were asked to prioritize the, factor groups and, they have been asked to choose the constructs' importance in a 5-point Likert scale, through on line questionnaire. Finally, the priorities were measured using GMM methodology. GCI of individual responses were also measured to check the consistency. Consensus has been achieved as GCI $\left(K^{v_{i}}\right) \leq 0.037$. Priority vector has been obtained after aggregating the individual judgements using GMM methodology i.e. $(0.4425,0.2226$, $0.1540,0.1244,0.0565)$. In the next level, aggregated judgements were also checked for the consistency and group Consensus has been achieved as GCCI $\left(K^{v(c)} \leq 0.037\right.$. All the constructs were also analyzed and weightages within the group and aggregated weightages have been estimated. 


\section{$5 \quad$ Results}

Based on the individual judgements, weightage of all the factor groups and constructs weightages have been estimated. The result has been provided below in Table 2 .

Table 2. Result of group decision on assessment of open government data initiative

\begin{tabular}{|c|c|c|c|}
\hline $\begin{array}{l}\text { Fac- } \\
\text { tor } \\
\text { groups }\end{array}$ & $\begin{array}{l}\text { Factor } \\
\text { groups } \\
\text { weight }\end{array}$ & Constructs & $\begin{array}{l}\text { Con- } \\
\text { structs } \\
\text { weight }\end{array}$ \\
\hline \multirow{6}{*}{ People } & \multirow{6}{*}{0.4425} & $\begin{array}{l}\text { Perceived usefulness of open government data among } \\
\text { users }\end{array}$ & 0.0749 \\
\hline & & Awareness of open government data among citizens & 0.0747 \\
\hline & & $\begin{array}{l}\text { Engagement and adaptation of open government data by } \\
\text { civil society }\end{array}$ & 0.0736 \\
\hline & & User friendly and ease of use of platform & 0.0736 \\
\hline & & User satisfaction on open government data & 0.0736 \\
\hline & & $\begin{array}{l}\text { Participatory governance for social benefit through col- } \\
\text { laboration with all stakeholders i.e. government bodies, } \\
\text { academia, private organizations and people }\end{array}$ & 0.0720 \\
\hline \multirow{5}{*}{$\begin{array}{l}\text { Econ- } \\
\text { omy }\end{array}$} & \multirow{5}{*}{0.2226} & Cost saving due to open government data & 0.0454 \\
\hline & & Cost of accessing open government data & 0.0451 \\
\hline & & Affordability of using open government data services & 0.0449 \\
\hline & & Sustainable funding for open government data initiative & 0.0437 \\
\hline & & Cost to government for sharing open government data & 0.0435 \\
\hline \multirow{5}{*}{$\begin{array}{l}\text { Tech- } \\
\text { nology } \\
\text { scope }\end{array}$} & \multirow{5}{*}{0.1540} & Accessibility of open government data & 0.0325 \\
\hline & & $\begin{array}{l}\text { Infrastructure of Open Government Data (OGD) plat- } \\
\text { form and to build new products/services based on open } \\
\text { government data }\end{array}$ & 0.0313 \\
\hline & & $\begin{array}{l}\text { Website maturity/stability of Open Government Data } \\
\text { (OGD) platform }\end{array}$ & 0.0305 \\
\hline & & Reliability of open government data & 0.0299 \\
\hline & & $\begin{array}{l}\text { Technological risk for uninterrupted access of open } \\
\text { government data }\end{array}$ & 0.0298 \\
\hline \multirow{7}{*}{ Policy } & \multirow{7}{*}{0.1244} & $\begin{array}{l}\text { Existence of open government data sharing policy and } \\
\text { open government data license }\end{array}$ & 0.0198 \\
\hline & & $\begin{array}{l}\text { Protection of privacy and sensitive information in open } \\
\text { government data }\end{array}$ & 0.0197 \\
\hline & & $\begin{array}{l}\text { Accountable and transparent governance by sharing } \\
\text { open government data }\end{array}$ & 0.0186 \\
\hline & & Effectiveness of open government data & 0.0175 \\
\hline & & $\begin{array}{l}\text { Policy to make data authentic and reliable to build trust } \\
\text { of the users }\end{array}$ & 0.0169 \\
\hline & & Security policies for website and data & 0.0164 \\
\hline & & $\begin{array}{l}\text { Policy to empower citizens to take informed and data } \\
\text { driven decision }\end{array}$ & 0.0154 \\
\hline \multirow{3}{*}{$\begin{array}{l}\text { Institu- } \\
\text { tion }\end{array}$} & \multirow{3}{*}{0.0565} & Quality of open government data/metadata & 0.0106 \\
\hline & & Availability of datasets & 0.0106 \\
\hline & & $\begin{array}{l}\text { Management support for open government data initia- } \\
\text { tive }\end{array}$ & 0.0094 \\
\hline
\end{tabular}




\begin{tabular}{|l|l|r|}
\hline & $\begin{array}{l}\text { Quality of services provided by Open Government Data } \\
\text { (OGD) platform }\end{array}$ & 0.0092 \\
\cline { 2 - 3 } & Operational efficiency to share the datasets & 0.0087 \\
\cline { 2 - 3 } & $\begin{array}{l}\text { Performance of open government data sharing mecha- } \\
\text { nism }\end{array}$ & 0.0080 \\
\hline
\end{tabular}

In the above table, factor groups weight column provides the result based on individual prioritization using GMM method and constructs weight column shows the outcome of their weightage based on the factor groups weight and their individual weight. The implications have been discussed in detail in the next section.

\section{Conclusions}

ICT is the key enabler of open data initiative of the government to become more open, responsive, inclusive, transparent, accountable and efficient. Evidence based planning process is essential for socio-economic development and all this depends on availability of up-to-date and quality government data. In the result of the assessment factor people has the highest weightage on open government data initiative. Apparently, citizen centricity becomes the key factor for determining success of such an initiative. Economy and technology has the second and third weightage respectively. Concerns about policy and institution were found to have lower impact in successful implementation of open government data initiative.

As per the study, foremost priority of the open government data initiative should be on adopting a citizen centric model. This model needs a clear comprehension of human elements to understand why citizens (user groups) would proactively use open data and engage with the initiative. Core-essence of this model is to focus on the requirement of citizens from the perspectives of citizens themselves, on building value \& awareness of the people on the importance of leveraging the open data, to enable participatory governance by citizen engagement activities. Second priority should be to build economic model by providing competent and cost effective services i.e. open data and data related services, to the citizens. Focus should also be on sustainable funding for the initiative and economic benefit of the government through participatory governance by sharing open data, and extensive data sharing mechanism across various government bodies, which will automatically save time and cost and will also benefit decision makers to take quick action for nation building. Next priority should be on technology scope, technology plays a major role to provide uninterrupted and quality services to the citizen, special focus should be on accessibility and in developing robust infrastructure to provide uninterrupted services. When data is being made open for public, need is there for implementing a policy \& regulatory framework, which grants access, use and distribute the open data without much restrictions. So, there should be a strong policy framework while implementing open government data. Last but not the least there is always a need of positive intent from the government bodies to share the data in open domain, hence availability \& quality of data/metadata with management support plays a big role in open government data initiative. 


\section{References}

1. Aguaron, Juan, and José María Moreno-Jiménez.: The geometric consistency index: Approximated thresholds. European journal of operational research 147(1), 137-145 (2003).

2. Al Hujran, O., Aloudat, A., \& Altarawneh, I.: Factors influencing citizen adoption of egovernment in developing countries: The case of Jordan. International Journal of Technology and Human Interaction (IJTHI) 9(2), 1-19 (2013).

3. AlBalushi, T. H., \& Ali, S.: Evaluation of the quality of E-government services: Quality trend analysis. In Information and Communication Technology Research (ICTRC), 2015 International Conference on, pp. 226-229. IEEE, Abu Dhabi (2015).

4. Alenezi, H., Tarhini, A., \& Sharma, S. K.: Development of quantitative model to investigate the strategic relationship between information quality and e-government benefits. Transforming Government: People, Process and Policy 9(3), 324-351 (2015).

5. Amritesh, C. Misra, S., \& Chatterjee, J.: Conceptualizing e-government service quality under credence based settings: A case of e-counseling in India. International Journal of Quality \& Reliability Management 31(7), 764-787 (2014).

6. Anand, O., Mittal, A., Moolchandani, K., Kagzi, M. M., \& Kar, A. K.: Evaluating travel websites using WebQual: A group decision support approach. Intelligent distributed computing, pp. 151-160. Springer International Publishing, Cham (2015).

7. Arzberger, Peter, et al.: An international framework to promote access to data. Science 303(5665), 1777-1778 (2004).

8. Attard, Judie, et al.: A systematic review of open government data initiatives. Government Information Quarterly 32(4), 399-418 (2015).

9. Bhatnagar, Subhash C., and Nupur Singh.: Assessing the Impact of E-government: A Study of Projects in India. Information Technologies \& International Development 6(2), pp.109127. Information Technologies \& International Development, Los Angeles (2010).

10. Buckley, James J.: Fuzzy hierarchical analysis. Fuzzy sets and systems 17(3), 233-247 (1985).

11. Cao, Dong, Lawrence C. Leung, and J. S. Law.: Modifying inconsistent comparison matrix in analytic hierarchy process: A heuristic approach. Decision Support Systems 44(4), 944953 (2008).

12. Chan, F. K., Thong, J. Y., Venkatesh, V., Brown, S. A., Hu, P. J., \& Tam, K. Y.: Modeling citizen satisfaction with mandatory adoption of an e-government technology. Journal of the Association for Information Systems 11(10), 519-549 (2010).

13. Conradie, Peter, and Sunil Choenni.: Exploring process barriers to release public sector information in local government. Proceedings of the 6th International Conference on Theory and Practice of Electronic Governance. ACM, pp. 5-13, ICEGOV, New York (2012).

14. Crawford, Gordon, and Cindy Williams.: A note on the analysis of subjective judgment matrices. Journal of mathematical psychology 29(4), 387-405 (1985).

15. Dong, Yucheng, et al.: Consensus models for AHP group decision making under row geometric mean prioritization method. Decision Support Systems 49(3), 281-289 (2010).

16. Economides, A. A., \& Terzis, V.: Evaluating tax sites: an evaluation framework and its application. Electronic Government, an International Journal 5(3), 321-344 (2008).

17. Escobar, María Teresa, Juan Aguarón, and José María Moreno-Jiménez.: A note on AHP group consistency for the row geometric mean priorization procedure. European Journal of Operational Research 153(2), 18-322 (2004).

18. Fan, J., Zhang, P., \& Yen, D. C.: G2G information sharing among government agencies. Information \& Management, 51(1), 120-128 (2014). 
19. Fitsilis, P., L. Anthopoulos, and V. Gerogiannis.: Assessment frameworks of e-government projects: a comparison. the Proceedings of the 13th Panhellenic Conference on Informatics (PCI 2009), pp. 10-12. PCI, Corfu Island (2009).

20. Funilkul, Suree, et al.: An evaluation framework for e-government services based on principles laid out in COBIT, the ISO 9000 standard, and TAM. ACIS 2006 Proceedings, 3. Adelaide (2006).

21. Government Open Data License - India, https://data.gov.in/sites/default/files/Gazette_Notification_OGDL.pdf, last accessed 2017/05/12.

22. Harjit Singh, Arpan Kumar Kar, P. Vigneswara Ilavarasan.: Assessment of e-Governance Projects: An Integrated Framework and its Validation. ICEGOV '17 SCII, New Delhi (2017).

23. Heeks, R.: Benchmarking e-government: improving the national and international measurement, evaluation and comparison of e-government. Evaluating Information Systems, 257. Elsevier, Hungary (2006).

24. Implementation Guidelines for National Data Sharing and Accessibility Policy (NDSAP) of India, https://data.gov.in/sites/default/files/NDSAP_Implementation_Guidelines_2.2.pdf, last accessed 2017/05/12.

25. Janssen, Marijn, Yannis Charalabidis, and Anneke Zuiderwijk.: Benefits, adoption barriers and myths of open data and open government. Information systems management 29(4), 258268 (2012).

26. Kar, Arpan Kumar, and Atanu Rakshit.: Flexible pricing models for cloud computing based on group decision making under consensus. Global Journal of Flexible Systems Management 16(2), 191-204 (2015).

27. Kar, Arpan Kumar, and Atanu Rakshit.: Pricing of Cloud IaaS Based on Feature Prioritization-A Value Based Approach. Recent Advances in Intelligent Informatics, pp. 321-330. Springer International Publishing, Cham (2014).

28. Kar, Arpan Kumar.: Integrating websites with social media-An approach for group decision support. Journal of Decision Systems 24.3, 339-353 (2015).

29. Khatwani, Gaurav, and Arpan Kumar Kar.: Improving the Cosine Consistency Index for the analytic hierarchy process for solving multi-criteria decision making problems. Applied Computing and Informatics, Elsevier, Hungary (2016).

30. Kumar Kar, Arpan, and Ashis K. Pani.:Exploring the importance of different supplier selection criteria. Management Research Review 37(1), 89-105 (2014).

31. Kumar, V., Mukerji, B., Butt, I., \& Persaud, A.: Factors for successful e-government adoption: a conceptual framework. The electronic journal of e-government 5(1), 63-76 (2007).

32. Mates, P., Lechner, T., Rieger, P., \& Pěkná, J.: Towards e-government project assessment: European approach. ZbornikradovaEkonomskogfakulteta u Rijeci, časopiszaekonomskuteorijuipraksu-Proceedings of Rijeka Faculty of Economics, Journal of Economics and Business 31(1), 103-125 (2013).

33. Mennis, Edmund A.: The Wisdom of Crowds: Why the Many Are Smarter than the Few and How Collective Wisdom Shapes Business, Economies, Societies, and Nations. Business Economics 41(4), 63-65 (2006).

34. Misra, D. P., and Alka Mishra.: Societal and Economical Impact on Citizens through Innovations Using Open Government Data: Indian Initiative on Open Government Data. Handbook of Research on Cultural and Economic Impacts of the Information Society, pp. 147178. IGI Global, Salamanca (2015).

35. Misra, Durga Prasad, and Neeta Verma.: Enabling Public Participation through E-Governance: An Indian Context. IJeN 2(1), 20-41 (2014). 
36. Misra, Mishra, Babbar, Gupta.: Open Government Data Policy and Indian Ecosystems. ICEGOV '17 SCII, New Delhi (2017).

37. National Data Sharing and Accessibility Policy-2012, https://data.gov.in/sites/default/files/NDSAP.pdf, last accessed 2017/05/12.

38. Panopoulou, E., Tambouris, E., \& Tarabanis, K.: A framework for evaluating web sites of public authorities. In Aslib.Proceedings, Vol. 60, No. 5, pp. 517-546. Emerald Group Publishing Limited, Bingley (2008).

39. Porumbescu, Gregory A.: Placing the Effect? Gleaning Insights into the Relationship between Citizens' Use of E-Government and Trust in Government. Public Management Review 18(10), 1504-1535 (2016).

40. Rotchanakitumnuai, S.: Measuring e-government service value with the E-GOVSQUALRISK model. Business Process Management Journal, 14(5), 724-737 (2008).

41. Saaty, T.L.: Multicriteria Decision Making: The Analytic Hierarchy Process. McGraw-Hill, New York (1980).

42. Sapru, R. K., and Yudhishthira Sapru. : Good governance through e-governance with special reference to India. Indian Journal of Public Administration, 60(2), 313-331 (2014).

43. Sharma, S. K., Govindaluri, S. M., \& Gattoufi, S.: Understanding and predicting the quality determinants of e-government services: A two-staged regression-neural network model. Journal of Modelling in Management, 10(3), 325-340 (2015).

44. Singh Kalsi, N., \& Kiran, R.: E-governance success factors: An analysis of e-governance initiatives of ten major states of India. International Journal of Public Sector Management, 26(4), 320-336 (2013).

45. Tomashevskii, I. L.: Eigenvector ranking method as a measuring tool: Formulas for errors. European Journal of Operational Research, 240(3),774-780 (2015).

46. Tsohou, A., Lee, H., Irani, Z., Weerakkody, V., Osman, I. H., Anouze, A. L., \& Medeni, T.: Proposing a reference process model for the citizen-centric evaluation of e-government services. Transforming Government: People, Process and Policy, 7(2), 240-255 (2013).

47. Ubaldi, B.: Open Government Data: Towards Empirical Analysis of Open Government Data Initiatives. OECD Working Papers on Public Governance, No. 22, 0_1. OECD Publishing, Paris (2013).

48. Verma, Neeta, and M. P. Gupta.: Open government data: beyond policy \& portal, a study in Indian context. Proceedings of the 7th International Conference on Theory and Practice of Electronic Governance, pp. 338-341. ACM, Seoul (2013).

49. Xu, J.: Measurement of public satisfaction evaluation on e-government: based on structural equation model. 2009 IITA International Conference on Control, Automation and Systems Engineering, pp. 418-421. IEEE, Zhangjiajie (2009).

50. Zimmermann, Hans-Jürgen.: Fuzzy set theory-and its applications. 4th edition. Springer Science \& Business Media New York (2011).

51. Zuiderwijk, Anneke, and Marijn Janssen.: Barriers and development directions for the publication and usage of open data: A socio-technical view. Open government, pp. 115-135. Springer, New York (2014). 